\title{
IMPACT OF CHANGING ABSORBER SHAPE ON AN AIR FLOW BEHAVIOR IN A THERMO-SOLAR CONVERTER
}

\author{
Hamidou Benzenine $1,2 \square$ (ID) Said Abboudi $2 \square$ (ID), Saim Rachid $3 \square$ (iD) \\ ${ }^{1}$ Department of Mechanical Engineering, faculty of science and technology, University of BELHADJ Bouchaib, \\ P.O.B. 284 RP, Ain Témouchent, 46000, Algeria. \\ ${ }^{2}$ Laboratory of Energetic and Applied Thermal ETAP, Department of Mechanical Engineering, Faculty of \\ Technology, P.O.B. 230, University of Tlemcen, 13000, Algeria. \\ ICB, UMR 6303 CNRS, Department COMM UTBM, University of Bourgogne Franche-Comte, 90010 Belfort \\ Cedex, France.
}

\section{ABSTRACT}

Received 15 October 2021

Accepted 15 November 2021

Published 23 December 2021

CorrespondingAuthor

Hamidou Benzenine,

b.hamidou@yahoo.fr

DOI

10.29121/IJOEST.v5.i6.2021.248

Funding: This research received no specific grant from any funding agency in the public, commercial, or not-forprofit sectors.

Copyright: (C) 2021 The Author(s). This is an open access article distributed under the terms of the Creative Commons Attribution License, which permits unrestricted use, distribution, and reproduction in any medium, provided the original author and source are credited.

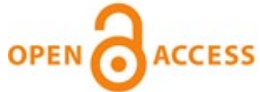

In this paper, a two-dimensional numerical study of heat exchange by forced convection of an incompressible laminar flow in a solar air heater duct (SAH), which is equipped with a shoulder attached to the absorber, was performed. The impact of three locations of this shoulder and their three heights on friction losses, as well as the drag coefficient, the variations of velocity, and temperature at the exit section of the SAH, were analyzed for a volume flow rate in the range [20-80 $\mathrm{m} 3 / \mathrm{h}$.]. The results obtained numerically prove that the insertion of a shoulder on the absorber improves the heat transfer and the dynamics of the flow very significantly. An average temperature difference (inlet-outlet) of the collector of $23.51{ }^{\circ} \mathrm{C}$ at $29.94^{\circ} \mathrm{C}$ and $50.64{ }^{\circ} \mathrm{C}$ at $67.53^{\circ} \mathrm{C}$ is acquired respectively for the high and the low flow rates. This paper also showed that the height of the shoulder used can ensure an acceleration of the flow with an axial variation of the order of 1.25 up to 2.5 times (> twice) compared with the simple case.

Keywords: Solar Energy, CFD, Heat Transfer, Thermo-Solar Converter

\section{INTRODUCTION}

A mere half hour of the solar radiation received by our planet is equivalent to the world's yearly energy requirement Kalogirou (2004). The solar energy can be used in various processes, such as heating, cooking food at home, generating electricity, etc. Due to the simple design of solar air heaters (SAHs), they are used to trap solar radiation, which can be used to heat ambient air or water under atmospheric conditions. However, the low heat transfer coefficient of the air leading to insufficient heat exchange between the absorbent plate and the fluid in the solar collector and therefore resulting in poor performance and thermal efficiency. Several techniques have been introduced in the dynamic air of the solar collector, for increasing the heat transfer between the air and the absorber Varun et al. (2007), Yadav and Bhagoria (2013), Bhushan and Singh (2010), Saim et al. (2010). For the improvement of its thermal performance, several studies have been carried out to modify the passage of the airflow by using a porous or finned absorber, a corrugated shaped absorber or an artificially rough absorber with ribs of different shapes., sizes, orientations and positions Sukhatme (1996), Hans et al. (2009), Yeh et al. (1998), Yeh et al. (2000), Gbaha (1989), Hachemi (1992), Saim et al. (2013), Benzenine et al. (2013), 
Nasiruddin and Siddiqui (2006), Ahmed (2012), Benzenine et al. (2013), Saim et al. (2013). Using other methods, many authors have investigated and reported various experimental and numerical investigations. Concerning the flow passages in SAH, for example, Labed et al. (2012) made a comparison on the performance of doublepass and single- pass solar collectors (without obstacles, with rectangular obstacles and with trapezoidal obstacles). A similar arrangement of a square shape offset absorbent plate was used in an indirect solar dryer by Youcef-Ali and Desmons (2005). Ozgen et al. (2009) carried out an experimental study to treat the thermal performance of double-pass air heaters in the presence and absence of aluminum boxes, arranged in staggered rows and in order. Experiments carried out showed that the efficiency for the case of solar air heater, with bottles arranged not in order, is higher than the other two cases due to the more turbulence and the presence of dead zones in the air heater. Regarding the corrugated-sheets technique, in a regular pattern, the plates are molded, with smooth corrugation or other type. These help to increase the heat transfer surface. For this technique, the study refers to the studies of Liu et al. (2007a), Liu et al. (2007b). Another study of the thermal performance of double-pass solar air heaters with differently shaped "flat and Vcorrugated" plates was carried out by El-Sebaii et al. (2011a), El-Sebaii et al.(2011b). For porous type, such as plate with holes, metal sponges, etc. A porous absorbent plate can be used. Air is passed through the porous material, which helps to improve the heat exchange coefficient. The heat transfer surface will be increased due to the porosity; however, the pumping power will increase as the porosity is released. Here, the study give as examples the publications of Tong and London (1957), Bharadwaj et al. (1981), Aldabbagh et al. (2010), Omojaro and Aldabbagh (2010), Dhiman et al. (2012), Lalji et al. (2012), Gupta and Kaushik (2009), Languri et al. (2011), and Mittal and Varshney (2006). Regarding the technique of combining wire mesh with incorporated baffles, we refer to the work of El-Khawajah et al. (2011), El-Khawajah et al. (2015). The thermal performance of a SAH was ameliorated with a transparent honeycomb made of glass tubes by Zhang et al. (2009). Raschig rings were used by Öztürk and Demirel (2004) to control flow inside the SAH. The jet impingement type was studied by Chauhan et al. (2012) and Zukowski (2015). Overlapped glass plates were investigated by Selçuk (1971) and Sodha and Kumar (1984). The transpired type was studied by Badache et al. (2012), Chan et al. (2013), and Chan et al. (2014). For special designs as PV/T (Photo Voltaic/Thermal), there is an example the work of Solanki et al. (2009) and Kumar and Rosen (2011). Other studies have also been carried out on indirect-type solar drying systems, where the collector presents a main element of the dryer; the authors have confirmed that improving the efficiency of this system is directly related to the performance of the collector Dilip and Kumar (2004), Dilip (2007), Lyes and Azeddine (2003), Subarna et al. (2011), Ahmed-Zaïd et al. (2001).

From this research bibliography, it is seen that many solar collector improvement techniques have been proposed in the literature. Several studies have focused on the movement of air inside the solar dryer, and the way in which moisture and heat are evacuated. However, the integration of a shoulder as a geometric element attached to the absorber of the SAH is a new approach that has not been studied by earlier studies. Thus, this study addresses the effect of introducing a shoulder in the absorber to improve the performance of a flat air solar collector on the dynamic and thermal level. The influence of the location and height of this shoulder on the changes in temperature and velocity at the outlet of the collector are investigated. The absence of a shoulder was also treated as a comparison with the other cases and for different volume flow. 


\section{DESCRIPTION OF THE SYSTEM}

In this study, the geometric dimensions of the problem studied are based on the experimental data published by Labed et al. (2009). This is a solar air heater (SAH) comprising a single transparent glass $(5 \mathrm{~mm})$, a matt black absorber $(0.4 \mathrm{~mm}$, galvanized steel) and an insulator $(0.4 \mathrm{~mm})$. The two-dimensional geometric configuration treated in the present study is shown in Figure 1

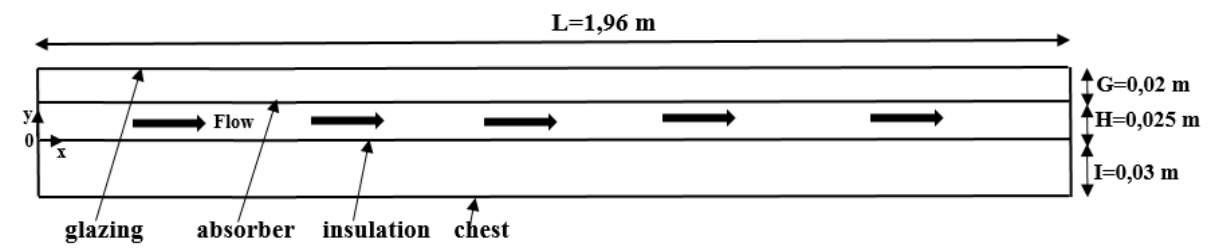

Figure 1 Descriptive diagram of the solar collector in our study

Figure $2 \mathrm{~b}, \mathrm{c}$ and d). The simple case of Figure 2 a was also examined and compared with the other cases

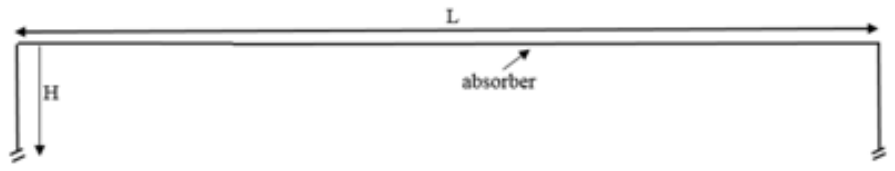

(a)

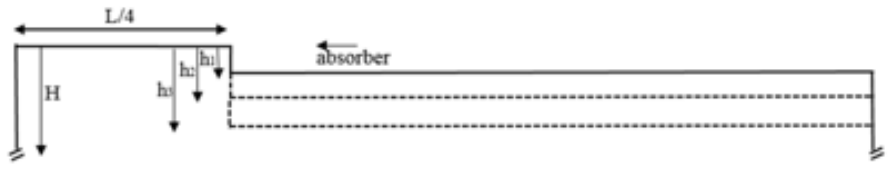

(b)

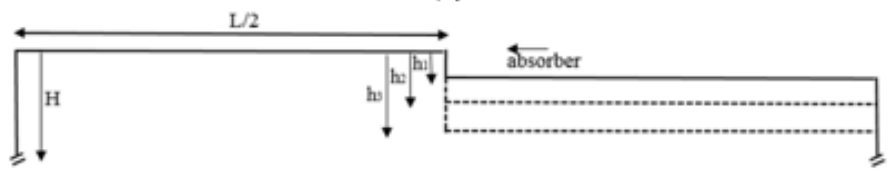

(c)

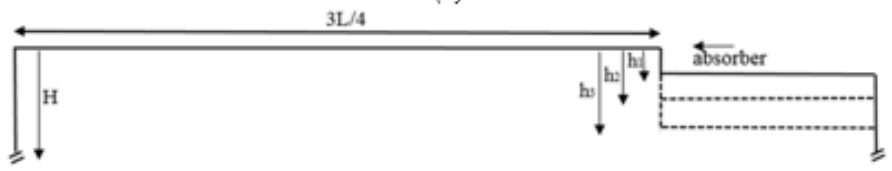

(d)

Figure 2 The cases treated: (a): simple case (without shoulder); with shoulder positioned: (b) at L/4 (Case 1), (c): at L/2 (Case 2), and (d): at 3L/4 (Case 3), with different heights

\section{CONSERVATION EQUATIONS}

The governing equations the air flow and the heat transfer in the solar collector plane namely: the equations of continuity, momentum and energy are given as follows: 


\section{Continuity:}

$$
\frac{\partial U}{\partial X}+\frac{\partial V}{\partial Y}=0
$$

\section{Momentum Equation:}

$$
\begin{aligned}
& \frac{\partial(U U)}{\partial X}+\frac{\partial(V U)}{\partial Y}=-\frac{1}{\rho} \frac{\partial P}{\partial X}+\left[\frac{\partial}{\partial X}\left(v \frac{\partial U}{\partial X}\right)+\frac{\partial}{\partial Y}\left(v \frac{\partial U}{\partial Y}\right)\right] \\
& \frac{\partial(U V)}{\partial X}+\frac{\partial(V V)}{\partial Y}=-\frac{1}{\rho} \frac{\partial P}{\partial Y}+\left[\frac{\partial}{\partial X}\left(v \frac{\partial V}{\partial X}\right)+\frac{\partial}{\partial Y}\left(v \frac{\partial V}{\partial Y}\right)\right]
\end{aligned}
$$

\section{Energy equation:}

$$
\rho_{0} C_{p}\left[\frac{\partial(U T)}{\partial X}+\frac{\partial(V T)}{\partial Y}\right]=\left[\frac{\partial}{\partial X}\left(K \frac{\partial T}{\partial X}\right)+\frac{\partial}{\partial Y}\left(K \frac{\partial T}{\partial Y}\right)\right]
$$

\section{Average friction coefficient:}

$$
\overline{C f}=\frac{2 \bar{\tau}_{w}}{\rho \cdot U^{2}}
$$

where $\tau_{-}^{-}$wis the average shear rate at the wall, $U$ the average axial velocity and ? the density of the fluid.

\section{Drag coefficient:}

$$
C d=\frac{2 \Delta p}{\rho U_{0}^{2}}\left(\frac{A_{f}}{A_{0}}\right)
$$

Where Af and A0 are respectively the fluid flow cross-section and the bathed surface while $\Delta p$ represents the pressure loss between the ends of the pipe. The simplifying assumptions corresponding to this mathematical model are as follows:

- Stationary and two-dimensional flow is considered laminar

- The heat flow applied to the top wall is uniform

- The thermophysical properties of the solid and the fluid are considered constant

- The temperature and velocity profiles at the entrance of the collector are assumed constant

\section{Boundary Condition}

Uniform velocity and temperature are introduced at the entrance of the collector while atmospheric pressure is applied at the outlet. The lower wall is isolated while a radiative flux is applied to the wall of the absorber. This study was carried out in the range [20.80 m3 / h.] of the volume flow 


\section{Numerical Modeling}

The governing equations are solved on a staggered grid using a finite volume method Patankar (1980). The Fluent commercial code is used and the SIMPLE algorithm Patankar and Spalding (1972) is applied for velocity-pressure coupling; to discretize the convective terms, the second order QUICK scheme is used.

\section{Mesh Sensitivity Analysis}

A refined and concentric mesh in the vicinity of the absorber and the insulator in order to properly capture the strong variations of the gradients was applied.

The sensitivity of this mesh on the results is examined by carrying out a series of tests on the six grids 1000, 3000,6000, 10000, 15000 and 21000 . The relative error is obtained for the results of the maximum speed of the axial component., as well as the temperature at the outlet of the manifold, are presented in Table 1.

\begin{tabular}{|c|c|c|c|c|c|c|}
\hline & 1000 & 3000 & 6000 & 10000 & 15000 & 21000 \\
\hline $\mathrm{T}_{\text {out }}$ & 323,439 & 323,478 & 323,485 & 323,490 & 323,493 & 323,497 \\
\hline Error\% & - & 0,0121 & 0,0021 & 0,0013 & 0,00105 & 0,00108 \\
\hline $\mathbf{U}_{\max }$ & 12,971 & 13,178 & 13,216 & 13,230 & 13,235 & 13,238 \\
\hline Error\% & - & 15,706 & 0,2925 & 0,0988 & 0,0442 & 0,0227 \\
\hline
\end{tabular}

Finally, we have chosen the mesh with 15000 elements, which allows to obtain solutions with a minimal error.

\section{Model Validation}

Before treating our cases, we started by comparing our results with those obtained by Labed et al. (2009), by adopting its conditions used on a single-pass solar air sensor.

The comparison in terms of temperature variation at the outlet of the collector as a function of the flow rate shows good agreement with their experimental and theoretical results (Figure 3).

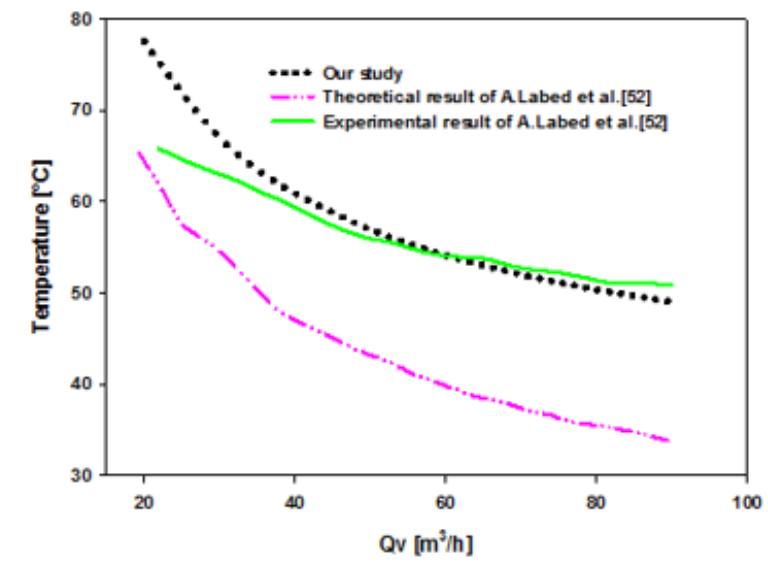

Figure 3 Variation and comparison of the outlet temperature as a function of the flow rate 


\section{RESULTS AND DISCUSSION}

A computational analysis has been performed to see the effects of shoulder attachment onto the absorber in solar air heater duct at different volume flow rate and temperatures.

Figure 4(a, b and c) clearly shows the change of the outlet temperature for different heights and locations for different cases and as a function of volume flow. As shown from general form of the result that temperature values are decreased with increasing of volumetric flowrate as expected. Difference among temperatures is diminished from case 1 to case 3 . It should also be noted that the lowest temperature values are recorded in the absence of the shoulder and that the outlet temperature becomes higher by increasing the height of the shoulder.

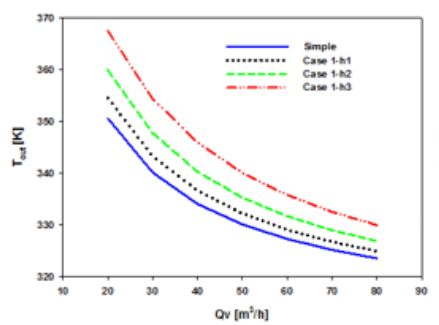

(a)

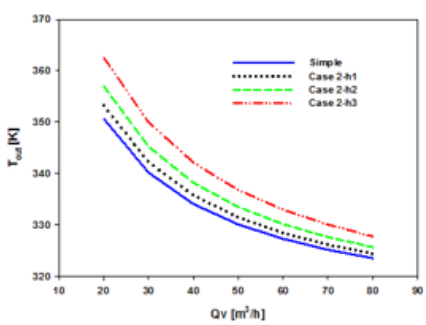

(b)

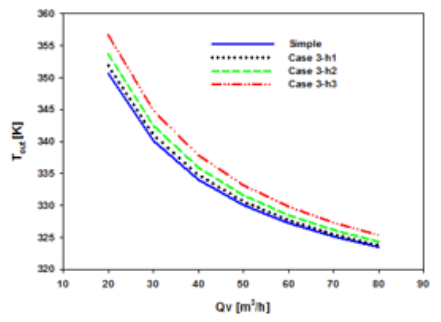

(c)

Figure 4 Evolution of the outlet temperature of the collector for different flow rate, different heights and locations: a) Case 1, b) Case 2 and c) Case 3

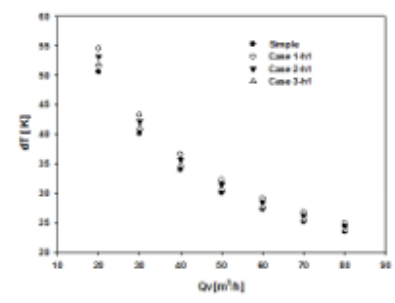

(a)

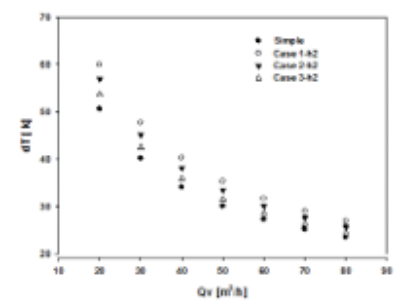

(b)

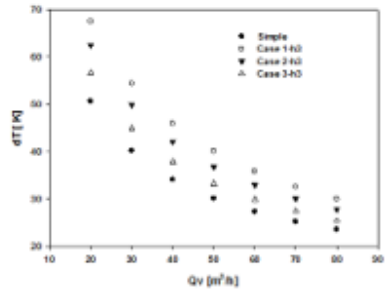

(c)

Figure 5 Variation of the temperature difference (input-output) as a function of flow rate with the different locations and heights: a) h1, b) h2and c) h3 
(Figure $5 \mathrm{a}, \mathrm{c}$ ) shows the downward variation of the temperature gradient (input-output) with the increase in flow. It is advantageous to use a low flow rate in order to prolong the exchange time. This indicated an important and thereafter a good temperature difference between the input and the output of the collector. Comparing the three figures as (Figure $5 \mathrm{a}, \mathrm{c}$ ), it is observed that as the height increases more, the difference in temperature between cases becomes greater. This is especially visible in the vicinity of lower flowrate.

Table 2 shows the differences in minimum and maximum temperatures, respectively, corresponding to the high and low flow rates $(80 \mathrm{~m} 3 / \mathrm{h}$ and $20 \mathrm{~m} 3 / \mathrm{h})$ for the different locations with different heights and for the simple case for comparison. It is very clear that the neutral case is that of the simple case and the presence of a shoulder, especially with an advanced positioning, results in more heat transfer enhancement. Increasing the height of the shoulder increases the exchange of the surface and therefore, it contributes to the heat transfer enhancement at any position.

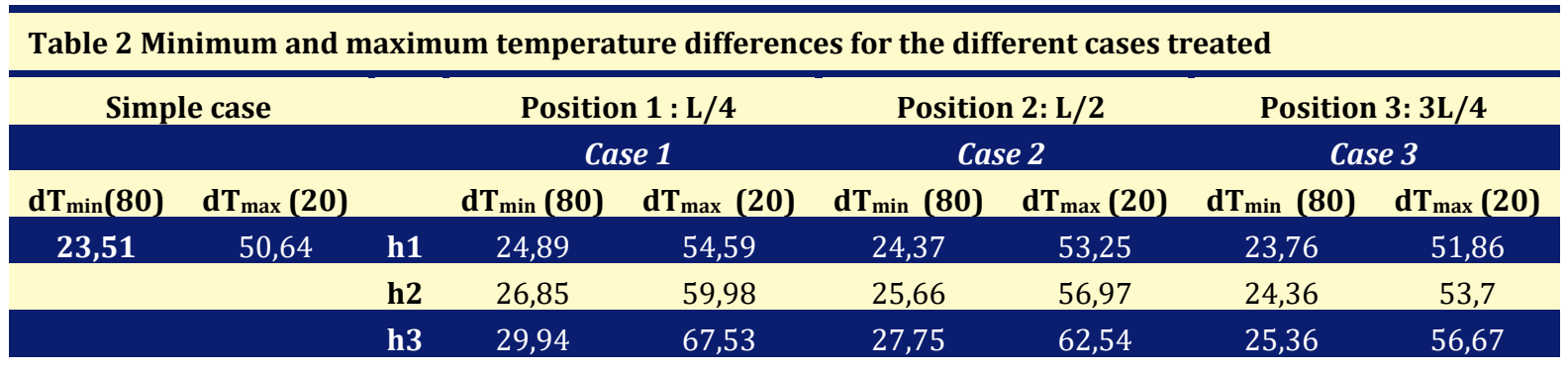

The variation of the coefficient of friction along the pipe provided with a shoulder placed in the middle (Case 2) is shown in (Figure $6 \mathrm{a}$, b). Thus, (Figure 6 , a) shows this variation for the greatest height, $h 3$, and for three different volume flow rates (20, 50 and $80 \mathrm{~m} 3 / \mathrm{h})$. Also, (Figure 6, b) illustrates this variation for the same volume flow rate $(50 \mathrm{~m} 3 / \mathrm{h})$ and for the three heights (h1, h2 and h3). As shown from the figures, the coefficient of friction is very low in the lower portion, and shows a drastic increase from the location of the shoulder. By passing this zone the coefficient takes constant higher values. It is also to be noted that the friction forces decrease with the increase of the velocity of the flow (Figure 6, a) and increases with the increasing of the height of the shoulder (Figure 6, b).

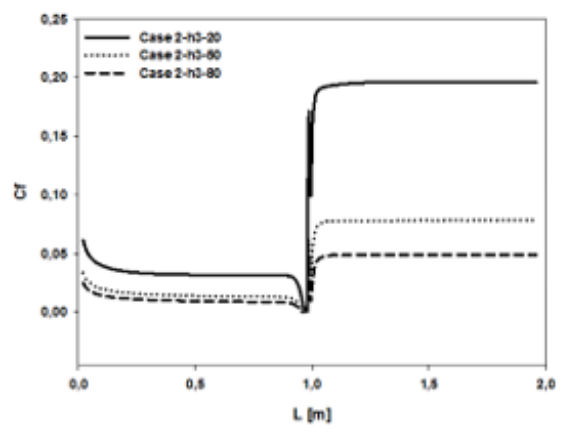

(a)

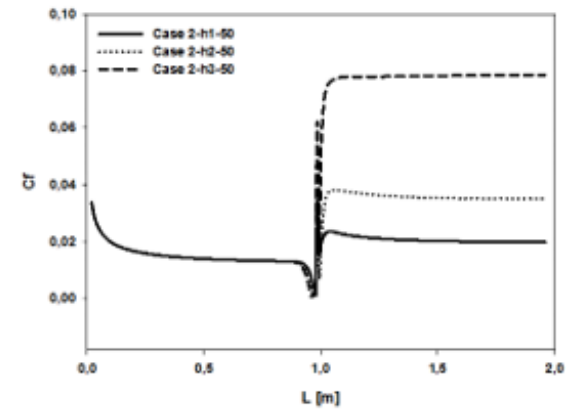

(b)

Figure 6 Evolution of the coefficient of friction along the absorber provided with a centered shoulder (Case 2) a) for different velocities and a constant height $h 3$, b) for different heights and a constant velocity 
Figure 7 gives the evolution of the ratio of drag forces compared to the simple case. It can be seen from the figure that the increase in the drag coefficient ratio is proportional to the height of the shoulder. Also, the losses generated by the first two heights ( 5 and $10 \mathrm{~mm}$ ) are not very significant if it is compared to the case h3 (15 $\mathrm{mm}$ ) for any locations. Moreover, a large shoulder (h3) placed at the entrance of the channel (Case 1) can result in a ratio of more than 100 times compared to the case without a shoulder., and therefore, for this study, presents an unfavorable case (not recommended).

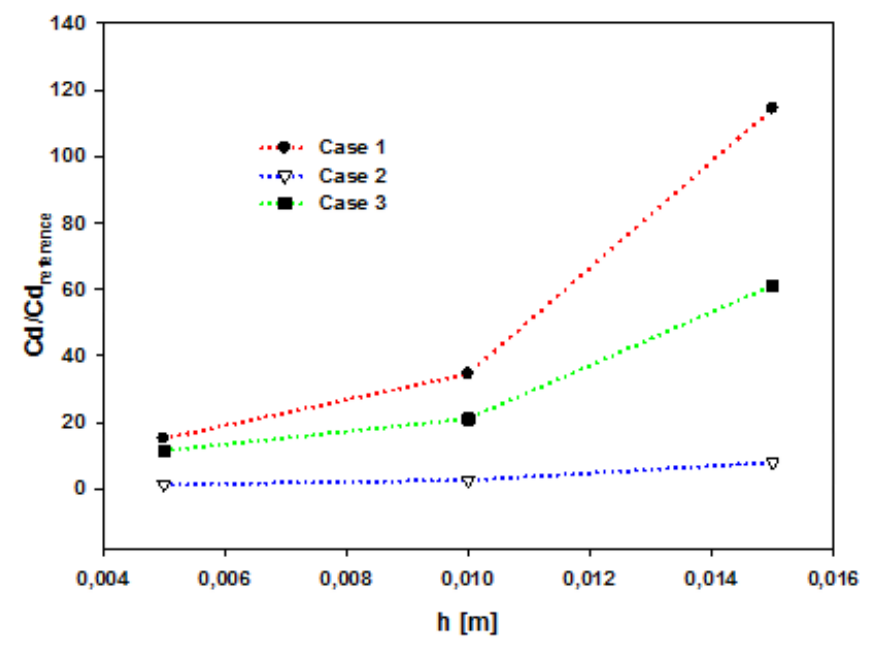

Figure 7 Evolution of the drag forces ratio according to the different heights

The presence of a shoulder in the air passage section results in a sudden narrowing of the passage section and therefore, it contributes to increase the ratio of the axial velocity to the inlet velocity as shown in Figure 8. From the fluid mechanics point of view, presence of the shoulder can help to accelerates to flow to increase the kinetic energy. Thus, heat transfer is increased with increasing of this kinetic energy.

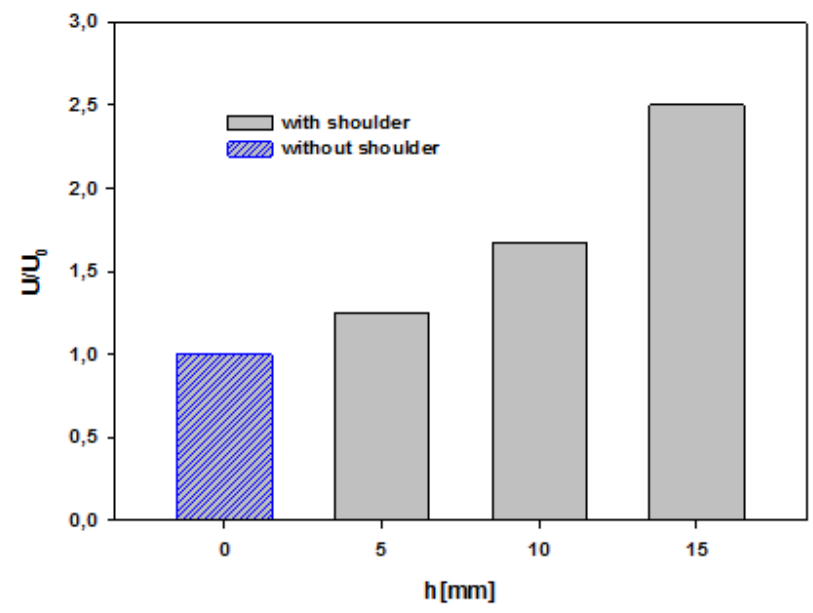

Figure 8 Evolution of the velocity ratio in the presence and absence of the shoulder

This acceleration of the air is very significant, and according to the type of application considered, for example the solar collectors used in the drying system, 
we see that the presence of a shoulder increases the circulation of air at the inlet of the drying chamber, and thus contributes to better air échapement wet at the exit of the chimney.

\section{CONCLUSION}

A numerical analysis, using the Fluent software, of heat transfer by forced convection of a laminar air flow in a flat solar collector was conducted. The analysis of the insertion impact of a shoulder on the absorber and the dynamic and thermal structure were studied for three heights and three locations in comparison with the simple case. Based on the results, it should be noted that:

- The addition of a shoulder in the system increases the exchange surface and reduces the passage section, which consequently improves the thermohydraulic efficiency of the system compared to the case without a shoulder.

- The temperature (inlet-outlet) of the collector is significantly low, ranging from (23.51 (simple case) up to $29.94^{\circ} \mathrm{C}$ (Case 1-h3)) for high flow rates. Then for low flows, it can reach (50.64 (simple case) up to $67.53^{\circ} \mathrm{C}$ (Case 1-h3)), so an interest is carried for these low flows which ensure more time of exchange.

- The use of one of the highest heights maximizes the temperature at the exit, but, on the other hand, considerably increases the friction and the drag.

- In order to increase the velocity ratio (U / U0) and accelerate the air at the output of the collector, the choice of the greatest height h3 makes it possible to obtain a gain of approximately $250 \%$ compared to the simple case.

\section{REFERENCES}

A A El-Sebaii, S Aboul-Enein, M R I Ramadan, S M Shalaby and B M Moharram, (2011a) Investigation of thermal performance of-double pass-flat and vcorrugated plate solar air heaters. Energy. ; 36, 1076-1086. Retrieved from https://doi.org/10.1016/j.energy.2010.11.042

A A El-Sebaii, S Aboul-Enein, M R I Ramadan, S M Shalaby and B M Moharram, (2011b) Thermal performance investigation of double pass-finned plate solar air heater. Applied Energy. ; 88, 1727-1739. Retrieved from https://doi.org/10.1016/j.apenergy.2010.11.017

A Ahmed-Zaïd, A Moulla, M S Hantala and J'Y Desmons, (2001) Amélioration des Performances des Capteurs Solaires Plans à Air : Application au Séchage de l'Oignon Jaune et du Hareng. Rev. Energ. Ren. ; 4, 69-78 Retrieved from https://www.asjp.cerist.dz/en/downArticle/401/4/2/118012

A Hachemi, (1992), Contribution à l'optimisation des performances thermiques des insolateurs plan a air, a lit garni de rangées d'obstacles aux pas serres. Amelioration du rendement par interaction entre le rayonnement et la convention, Ph.D. Thesis. University of Valenciennes. France.

A Labed, N Moummi, A Benchabane, K Aoues and A Moummi, (2012) Performance investigation of single- and double-pass solar air heaters through the use of various fin geometries. International Journal of Sustainable Energy. ; 31, 435-435. doi :10.1080/14786451.2011.649837 Retrieved from https://doi.org/10.1080/14786451.2011.649837

A Labed, N Moummi, K Aouès, M Zellouf and A. Moummi, (2009) Etude théorique et expérimentale des performances d'un capteur solaire plan à air muni d'une 
nouvelle forme de rugosité artificielle, Revue des Energies Renouvelables. ; 12 (4), $\quad 551 \quad$ - $\quad 561 \quad$ Retrieved from https://revue.cder.dz/index.php/rer/article/view/161

A P P Omojaro and L B Y Aldabbagh, (2010) Experimental performance of single and double pass solar air heater with fins and steel wire mesh as absorber. Applied Energy. ; 87, 3759-3765. Retrieved from https://doi.org/10.1016/j.apenergy.2010.06.020

A S Yadav and J L Bhagoria, (2013) Heat transfer and fluid flow analysis of solar air heater : A review of CFD approach. Renewable and Sustainable Energy reviews. ; 23, 60-79. Retrieved from https://doi.org/10.1016/j.rser.2013.02.035

B Bhushan and R Singh, (2010) A review on methodology of artificial roughness used in duct of solar air heaters. Energy. ; 35, 202-212. Retrieved from https://doi.org/10.1016/j.energy.2009.09.010

B Lyes and B Azeddine, (2003) Design and simulation of a solar dryer for agriculture products. Journal of Food Engineering. ; 59, 259-266 Retrieved from https://doi.org/10.1016/S0260-8774(02)00466-1

E M Languri, H Taherian, K Hooman and J Reisel, (2011) Enhanced Double-Pass Solar Air Heater With and Without Porous Medium. International Journal of Green Energy. ; 8, 643-654. Retrieved from https://doi.org/10.1080/15435075.2011.600379

F Ozgen, M Esen and H Esen, (2009) Experimental investigation of thermal performance of a double-flow solar air heater having aluminium cans. Renewable Energy. ; 34, 2391-2398. Retrieved from https://doi.org/10.1016/j.renene.2009.03.029

H M Yeh, C D Ho and C Y Lin, (2000) Effect of collector aspect ratio on the collector efficiency of upward type baffled solar air heaters. Energy Conversion Manage. ; 41, 971-81. Retrieved from https://doi.org/10.1016/S01968904(99)00148-X

H Benzenine, R Saim, S Abboudi and O Imine (2013). Numerical analysis of a turbulent flow in a channel provided with transversal waved baffles, Thermal Science International Scientific Journal. ; 17(3), 801-812. Retrieved from https://doi.org/10.2298/TSCI111004099B

H Benzenine, R Saim, S Abboudi, and O Imine, (2013) Numerical study on turbulent flow forced convection heat transfer for air in channel with waved fins. MECHANIKA. ; 19(2), 150-158. ISSN : 2029-6983(electronic) 1392-1207. Retrieved from https://doi.org/10.5755/j01.mech.19.2.4154

H H Öztürk and Y Demirel, (2004) Exergy-based performance analysis of packedbed solar air heaters. International Journal of Energy Research. ; 28, 423432. Retrieved from https://doi.org/10.1002/er.974

H M Yeh, CD Ho and C Y Lin, (1998) The influence of collector aspect ratio on the collector efficiency of baffled solar air heaters. Energy, ; 23(1), 11-6. Retrieved from https://doi.org/10.1016/S0360-5442(97)00054-6

H Y Y Chan, J Zhu and S Riffat, (2013) Heat transfer analysis of the transpired. solar Energy Procedia .; 42, 123-132. Retrieved from https://doi.org/10.1016/j.cyto.2013.06.045

H Y Y Chan, J Zhu, M H Ruslan, K Sopian and S Riffat, (2014) Thermal analysis of transpired solar facades. Energy Procedia. ; 48, 1345-1354. Retrieved from https://doi.org/10.1016/j.egypro.2014.02.152

J Dilip and J Rajeev Kumar, (2004) Performance evaluation of an inclined multi-pass solar air heater with in-built thermal storage on deep-bed drying 
application. Journal of Food Engineering. ; 65, 497-509 Retrieved from https://doi.org/10.1016/j.jfoodeng.2004.02.013

J Dilip, (2007) Modeling the performance of the reversed absorber with packed bed thermal storage natural convection solar crop dryer. Journal of Food Engineering. ; 78, 637-647 Retrieved from https://doi.org/10.1016/j.jfoodeng.2005.10.035

K Selçuk, (1971) Thermal and economic analysis of the overlapped-glass plate solarair heater. Solar Energy. ; 13, 165-191. Retrieved from https://doi.org/10.1016/0038-092X(71)90002-8

L B Y Aldabbagh, F Egelioglu and M Ilkan, (2010) Single and double pass solar air heaters with wire mesh as packing bed. Energy. ; 35, 3783-3787. Retrieved from https://doi.org/10.1016/j.energy.2010.05.028

Le S Tong and A La London, (1957) Heat transfer and flow friction characteristics of cover screen and cross rod matrices. Trans, ASME. ; 79, 1558-1570. Retrieved from https://doi.org/10.21236/ADA286687

M Badache,D Rousse, S Hallé, G Quesada and Y Dutil, (2012) Experimental and twodimensional nmerical simulation of an unglazed transpired solar air collector. Energy Procedia. ; 30, 19-28. Retrieved from https://doi.org/10.1016/j.egypro.2012.11.004

M F El-Khawajah, F Egelioglu and M Ghazal, (2015) Finned Single-pass Solar Air Heaters wit Wire Mesh as an Absorber Plate. International Journal of Green Energy. ; 12,108-116 Retrieved from https://doi.org/10.1080/15435075.2014.889016

M F El-Khawajah, L B Y Aldabbagh, and F Egelioglu, (2011) The effect of using transverse fin on a doublé pass flow solar air heater using wire mesh as an absorber, Solar Energy. ; 85, 1479-1487. Retrieved from https://doi.org/10.1016/j.solener.2011.04.004

M H Nasiruddin and Kamran Siddiqui, (2006) Heat transfer augmentation in a heat exchanger tube using a baffle. International Journal of Heat and Fluid Flow. ; 2, 28, 318-328. Retrieved from https://doi.org/10.1016/j.ijheatfluidflow.2006.03.020

M K Chauhan, Varun and S Chaudhary, (2012) Performance evaluation of roughened solar air heater having $\mathrm{M}$-shaped as roughness geometry on the absorber plate. International Journal of Energy and Environment. ; 3 (6), 881-894. Retrieved from https://web.p.ebscohost.com/abstract?direct=true\&profile=ehost\&scope= site \&authtype $=$ crawler\&jrnl $=20762895 \& A N=84557340 \& \mathrm{~h}=\mathrm{yfG} \% 2 \mathrm{bj} 4 \mathrm{Dg} 4$ DI5qWRDk3ITgqkuLIfXvypvPAt2R1s\%2bG\%2bk30\%2fRbdaeMUrubYzgG PE21k80k5EvcbEw5TBeoAPnYrQ\%3d\%3d\&crl=c\&resultNs=AdminWebA uth\&resultLocal=ErrCrlNotAuth\&crlhashurl=login.aspx\%3fdirect\%3dtrue \%26profile\%3dehost\%26scope\%3dsite\%26authtype\%3dcrawler\%26jrnl \%3d20762895\%26AN\%3d84557340

M K Gupta and S C Kaushik, (2009) Performance evaluation of solar air heater having expanded metal mesh as artificial roughness on absorber plate. International Journal of Thermal Sciences. ; 48, 1007-1016. Retrieved from https://doi.org/10.1016/j.ijthermalsci.2008.08.011

M K Lalji, R M Sarviya and J L Bhagoria, (2012) Exergy evaluation of packed bed solar air heater. Renewable and Sustainable Energy Reviews. ; 16, 6262-6267. Retrieved from https://doi.org/10.1016/j.rser.2012.04.024 
M K Mittal and L Varshney, (2006) Optimal thermohydraulic performance of a wire mesh packed solar air heater. Solar Energy. ; 80,1112-1120. Retrieved from https://doi.org/10.1016/j.solener.2005.10.004

M S Sodha and A Kumar, (1984) A simple thermal model of an overlapped-glass plate solar airheater. Energy Conversion and Management. ; 24, 287-295. Retrieved from https://doi.org/10.1016/0196-8904(84)90008-6

M Saber Ahmed, (2012) TaifSeraji, JonaidJahedi and M A Hashib, Application of CFD for simulation of a baffled tubular membrane. chemical engineering research and design.; 90, 600-608. Retrieved from https://doi.org/10.1016/j.cherd.2011.08.024

M Subarna, P Pankaj,V Kairavi, E Kruthika and K G Pushpito , (2011) Performance evaluation of a small scale indirect solar dryer with static reflectors during non-summer months in the Saurashtra region of western India. Solar Energy. ; 85, 2686-2696 Retrieved from https://doi.org/10.1016/j.solener.2011.08.007

M Zukowski, (2015) Experimental investigations of thermal and flow characteristics of a novel microjet air solar heater. Applied Energy. ; 142,10-20. Retrieved from https://doi.org/10.1016/j.apenergy.2014.12.052

P Dhiman, N S Thakur and S R Chauhan, (2012) Thermal and thermohydraulic performance of counter and parallel flow packed bed solar air heaters. Renewable Energy. ; 46, 259-268. Retrieved from https://doi.org/10.1016/j.renene.2012.03.032

P Gbaha, (1989), Etude et optimisation des échanges thermiques et des performances des capteurs solaires plans à deux veines d'air, Ph.D. Thesis. University of Valenciennes. France

R Kumar and M Rosen, (2011) Performance evaluation of a doublé pass PV/T solar air heater with and without fins. Applied Thermal Engineering. ; 31, 14021410. doi : 10.1016/j.applthermaleng.2010.12.037 Retrieved from https://doi.org/10.1016/j.applthermaleng.2010.12.037

R Saim, H Benzenine, H. F Oztop and K Al-Salem, (2013) Heat transfer enhancement of turbulent flow in a channel with diamond shaped baffles, Progress in Computational Fluid Dynamics An International Journal. ; 13, No. 6, Retrieved from https://doi.org/10.1504/PCFD.2013.057097

R Saim, H Benzenine,H F Oztop and K Al-Salem, (2013) Turbulent flow and heat transfer enhancement of forced convection over heated baffles in a channel: Effect of pitch of baffles. International Journal of Numerical Methods for Heat and Fluid Flow. ; 23 issue 4, 613-633. Retrieved from https://doi.org/10.1108/09615531311323773

R Saim, S Abboudi and B Benyoucef, (2010) Computational analysis of transient turbulent flow and conjugate heat transfer characteristics in a solar collector panel with internal, rectangular fins and baffles. Thermal Science. ; 14(1), 221-234. Retrieved from https://doi.org/10.2298/TSCI1001221S

S C Solanki, S Dubey and A Tiwari, (2009) Indoor simulation and testing of photovoltaic thermal (PV/T) air collectors. Applied Energy. ; 86, 2421-2428. Retrieved from https://doi.org/10.1016/j.apenergy.2009.03.013

S P Sukhatme, (1996), Solar Energy : Principles of Thermal Collection and Storage, Tata McGraw Hill Publishing Company Limited, New Delhi

S S Bharadwaj, D Singh and N K Bansal, (1981) Design and thermal performance of a matrix solar air heater. Energy Conversion and Management. ; 21, 253-256. Retrieved from https://doi.org/10.1016/0196-8904(81)90021-2 
S V Patankar and D B Spalding, (1972) A calculation procedure for heat, mass and momentum transfer in three-dimensional parabolic flows. International Journal of Heat and Mass Transfer. ; 15 1787-1806 Retrieved from https://doi.org/10.1016/0017-9310(72)90054-3

S V Patankar, (1980), Numerical Heat Transfer and Fluid Flow, Hemisphere, New York Retrieved from https://www.taylorfrancis.com/books/mono/10.1201/9781482234213/ numerical-heat-transfer-fluid-flow-suhas-patankar

S Youcef-Ali and J'Y Desmons, (2005) Simulation of a new concept of an indirect solar dryer equipped with offset rectangular plate fin absorber-plate. International Journal of Energy Research. ; 29, 317-334. Retrieved from https://doi.org/10.1002/er.1061

SA Kalogirou, (2004) Solar thermal collectors and applications. Progress in Energy \& Combustion Science. ; 30, 231-95. Retrieved from https://doi.org/10.1016/j.pecs.2004.02.001

T Liu, W Lin, W Gao and C Xia, (2007a) A comparative study of the thermal performances of cross-corrugated and v-groove solar air collectors. International Journal of Green Energy. ; 4, 427- 451. Doi : 10.1080/15435070701465847 Retrieved from https://doi.org/10.1080/15435070701465847

T Liu, W Lin, W Gao, C Luo, M Li, Q Zheng and C Xia, (2007b) A Parametric Study on the Thermal Performance of a Solar Air Collector with a V-Groove Absorber. International Journal of Green Energy. ; 4, 601-622. Retrieved from https://doi.org/10.1080/15435070701665370

V S Hans, R P Saini and J S Saini, (2009) Performance of artificially roughened solar air heaters, a review, Renew. Sust. Energ. Rev. ; 13, 1854-1869, Retrieved from https://doi.org/10.1016/j.rser.2009.01.030

Varun, R P Saini and S K Singal, (2007) A review on roughness geometry used in solar air heaters. Solar Energy. ; 81, 40-50. Retrieved from https://doi.org/10.1016/j.solener.2007.01.017

Z Zhang, R Zuo, P Liand W Su, (2009) Thermal performance of solar air collector with transparent honeycomb made of glass tube. Science in China, Series E : Technological Sciences. ; 52, 2323-2329. Retrieved from https://doi.org/10.1007/s11431-008-0179-5 